\title{
HUBUNGAN PENGETAHUAN IBU DAN DUKUNGAN KELUARGA DENGAN CAKUPAN PEMBERIAN IMUNISASI DASAR PADA BATITA DI DESA SANGSO KECAMATAN SAMALANGA KABUPATEN BIREUEN
}

\author{
The Relationship Between Mother Knowledge And Family \\ Support With Coverage Of Basic Immunization \\ In Sangso Village Samalanga Sub-district In Bireuen District
}

\author{
Minda Septiani*1, Zhuhra Mita*2 \\ 1. Dosen Akademi Kebidanan Munawarah, Jl. Sultan Iskandar Muda No.18 Kota Juang, Bireuen 24251, Indonesia \\ 2. Mahasiswi Akademi Kebidanan Munawarah, Jl. Sultan Iskandar Muda No.18 Kota Juang, Bireuen 24251, \\ Indonesia
}

*Korespondensi Penulis : mindaseptiani88@gmail.com*1

\begin{abstract}
ABSTRAK
Imunisasi adalah suatu tindakan memberikan kekebalan tubuh kepada seseorang dengan memasukkan vaksin agar kebal terhadap suatu penyakit.Vaksin merupakan bibit penyakit yang sudah dilemahkan. Penyakit yang dapat dicegah dengan jalan imunisasi contohnya difteri, tetanus, TBC, campak, dan polio. Penelitian ini bertujuan untuk mengetahui hubungan pengetahuan ibu dan dukungan keluarga dengan cakupan pemberian imunisasi dasar di Desa Sangso Kecamatan Samalanga Kabupaten Bireuen Tahun 2020.

Desain penelitian yang digunakan adalah penelitian analitik dengan pendekatan cross sectional. Penelitian ini telah dilakukan pada bulan Agustus 2020. Populasi dalam penelitian ini adalah seluruh ibu yang mempunyai anak usia 1-3 tahun yang ada di Desa Sangso Kecamatan Samalanga Kabupaten Bireuen sebanyak 81 orang. Teknik pengambilan sampel yaitu dengan cara total populasi yang diperoleh dengan melakukan kunjungan rumah (door to door) sebanyak 81 orang. Teknik analisis data univariat dan analisis bivariat menggunakan uji chi-square.

Hasil uji statistik chi-square antara hubungan pengetahuan Ibu dengan cakupan pemberian imunisasi dasar didapatkan nilai $\mathrm{p}(0,000)<\alpha(0,05)$ berarti ha diterima dan ho ditolak, dapat disimpulkan bahwa ada hubungan antara pengetahuan ibu dengan cakupan pemberian imunisasi dasar di Desa Sangso Kecamatan Samalanga Kabupaten Bireuen Tahun 2020. Hasil uji statistik chi-square antara dukungan keluarga dengan cakupan pemberian imunisasi dasar didapatkan nilai $\mathrm{p}(0,074)>\alpha(0,05)$ berarti ho diterima dan ha ditolak, dapat disimpulkan bahwa tidak ada hubungan antara dukungan keluarga dengan cakupan pemberian imunisasi dasar di Desa Sangso Kecamatan Samalanga Kabupaten Bireuen Tahun 2020.

Diharapkan kepada responden untuk lebih aktif mencari informasi khususnya tentang imunisasi dasar.
\end{abstract}

Kata Kunci : Pengetahuan, Dukungan Keluarga, Imunisasi Dasar 


\begin{abstract}
Immunization is an act of providing immunity to a person by entering the vaccine to be immune to a disease. Vaccine is a seed that has been attenuated disease. Diseases that can be prevented by immunization, for example diphtheria, tetanus, tuberculosis, measles, and polio. This study aims to determine the relationship of maternal knowledge and family support with the coverage of basic immunization in Sangso Village, Samalanga District, Bireuen District. This research is a type of analytic research with cross sectional approach. This research was conducted on August 2020. Sampling in this study using total population technique with the number of respondents 81 mothers who have children aged 1-3 years in Sangso Village, Samalanga District, Bireuen Regency. Univariate data analysis techniques and bivariate analysis using chi-square test.

The results of chi-square statistical test between the relationship of knowledge of mothers with basic immunization obtained $p$ value $(0.000)<\alpha(0.05)$ can be concluded that there is a relationship between the relationship of maternal knowledge with basic immunization in Sangso Village, Samalanga District, Bireuen District, 2020. The results of statistical tests between family support with basic immunization obtained $p(0.074)>\alpha(0.05)$, it can be concluded that there is no relationship between family support relationship with basic immunization in Sangso Village, Samalanga District, Bireuen District, 2020.

It is expected that respondents will be more active in seeking information, especially regarding basic immunization.
\end{abstract}

Keywords $\quad$ : Knowledge, Family Support, Basic Immunization

\title{
PENDAHULUAN
}

Menurut World Health Organization (WHO), Imunisasi dapat menjangkau semua lapisan masyarakat maka sasaran yang ditujukan ialah orang tua, khususnya pada ibu atau calon ibu untuk diberikan penyuluhan tentang pentingnya imunisasi bagi anak, menganjurkan agar ibu membawa anaknya ke Posyandu. Imunisasi merupakan bentuk intervensi kesehatan yang sangat efektif dalam menurunkan angka kematian bayi dan balita (Dewi, 2010).

Imunisasi bukan hanya program kesehatan di Indonesia tapi juga program dunia (WHO). Menurut data WHO sekitar 194 negara maju maupun berkembang tetap melakukan imunisasi rutin pada bayi dan balitanya. Negara maju dengan tingkat gizi dan lingkungan yang baik tetap melakukan imunisasi rutin pada semua bayinya, karena terbukti bermanfaat untuk bayi yang di imunisasi dan mencegah penyebaran kepada anak di sekitarnya. Setiap tahun sekitar 85-95\% bayi di negara-negara maju tersebut mendapat imunisasi rutin, sedangkan sisanya belum terjangkau imunisasi karena menderita penyakit tertentu, sulitnya 
Journal of Healthcare Technology and Medicine Vol. 6 No. 2 Oktober 2020

Universitas Ubudiyah Indonesia

e-ISSN : 2615-109X

akses terhadap layanan imunisasi, hambatan jarak, geografis, kemanan, sosial ekonomi dan lain-lain (Ritonga, 2014).

Penyelenggaraan imunisasi di Indonesia dimulai sejak tahun 1956 dan diperluas menjadi Program Pengembangan Imunisasi (PPI) pada tahun 1997 dalam rangka pencegahan penularan terhadap beberapa penyakit yang dapat dicegah dengan Imunisasi (PD31). Program imunisasi Indonesia diatur oleh Kementerian Kesehatan Republik Indonesia yang bertanggung jawab dalam menetapkan sasaran, jumlah penerima imunisasi, kelompok umur serta tata cara memberikan vaksin pada sasaran serta ditetapkan berdasarkan Peraturan Menteri Kesehatan Republik Indonesia Nomor: 42/Menkes/SK/VI/2013 tentang Penyelenggaraan Imunisasi, menyebutkan bahwa imunisasi adalah suatu upaya untuk menimbulkan atau meningkatkan kekebalan seseorang secara aktif terhadap suatu penyakit, sehingga bila suatu saat terpajan dengan penyakit tersebut tidak akan sakit atau hanya mengalami sakit ringan (Kemenkes RI, 2013).

Imunisasi adalah suatu tindakan memberikan kekebalan tubuh kepada seseorang dengan memasukkan vaksin agar kebal terhadap suatu penyakit. Dengan demikian, kelak bila ia terpapar suatu penyakit, hanya akan sakit ringan. Vaksin merupakan bibit penyakit yang sudah dilemahkan atau dimatikan. Imunisasi disebut juga dengan vaksinasi. Penyakit yang dapat dicegah dengan imunisasi contohnya difteri, tetanus, TBC, campak, dan polio. Imunisasi terutama diberikan pada bayi (Akmal, 2016).

Imunisasi penting untuk bayi. Antibodi yang dimiliki oleh bayi belum sempurna, oleh karena itu bayi memerlukan vaksin yang berupa imunisasi untuk menangkal berbagai macam penyakit yang dapat menyerang kapan saja. Bahaya yang dapat terjadi jika bayi tidak di imunisasi diantaranya yaitu bayi dapat terkena penyakit seperti, TBC, hepatitis, polio, tetanus, difteri, batuk rejan, radang selaput otak, pneumonia, infeksi telinga, campak, flu, gondokan, bahkan rubella. Dengan memberikan imunisasi, setidaknya akan memperkecil kemungkinan menularnya suatu virus atau bakteri yang dapat menimbulkan penyakit (Riyanti, 2015).

Penyakit yang dapat dicegah dengan Imunisasi (PD31) menyebabkan 1,5 juta kematian anak. Hal ini dapat dicegah dengan memberi imunisasi dasar lengkap pada anak. Terdapat 2-3 juta kematian anak di dunia setiap tahunnya dapat dicegah dengan pemberian imunisasi, namun sebanyak 22,6 juta anak di seluruh dunia tidak terjangkau imunisasi rutin. Di Indonesia lebih dari dari 13\% anak usia 0-11 bulan belum mendapatkan imunisasi dasar secara lengkap (Depkes RI, 2014). 
Journal of Healthcare Technology and Medicine Vol. 6 No. 2 Oktober 2020

Universitas Ubudiyah Indonesia

e-ISSN : 2615-109X

Pengetahuan tentang imunisasi mencakup tahu akan pengertian imunisasi, penyakit yang dapat dicegah melalui imunisasi, manfaat imunisasi, tempat pelayanan imunisasi, waktu pemberian imunisasi, jenis imunisasi dan jumlah pemberian imunisasi. Melalui pengetahuan yang cukup diharapkan dapat mempengaruhi tindakan seseorang ibu dalam memberikan imunisasi secara lengkap kepada anaknya (Agus, 2014).

Dukungan keluarga merupakan salah satu faktor penting untuk kelengkapan imunisasi karena dukungan keluarga akan mendorong orang tua untuk melakukan imunisasi yang dapat memproteksi anak-anak atau orang dewasa untuk melawan penyakit infeksi yang berbahaya (Ilham, 2017).

Dukungan keluarga dapat diwujudkan dengan memberikan dukungan informasi, dukungan penilaian/penghargaan, dukungan instrumental dan dukungan emosional/empati. Dukungan keluarga dapat diwujudkan dengan memberi perhatian, bersikap empati, memberikan dorongan, memberikan saran, memberi pengetahuan dan sebagainya (Ilham, 2017).

Sikap ibu yang positif terhadap imunisasi akan menjadi dasar tindakan ibu membawa anak ke pelayanan imunisasi. Faktor lain seperti dukungan keluarga, pekerjaan, pendapatan keluarga, dan terjangkaunya tempat pelayanan juga perlu menjadi bahan evaluasi (Pratiwi, 2012).

Data imunisasi di Indonesia berdasarkan data InfoDATIN (2016) pada tahun 2015 Indonesia belum dapat mencapai Universal Child Immunization (UCI) dari renstra 2014 UCI dinyatakan mencapai 100\%. Capaian UCI pada tahun 2014 dan 2015 adalah 86,9\% dan 86,5\% Sedangkan UCI Provinsi Kalimantan Barat adalah 72,4\%, merupakan posisi ke-6 terendah dari 30 provinsi yang telah memberikan atau melaporkan ke kemenkes RI, Dari jumlah 34 Provinsi di Indonesia.

Data dari provinsi Aceh tahun 2019 menyebutkan bahwa imunisasi BCG sebanyak 86.179 bayi $(73,8 \%)$, imunisasi $\mathrm{HB}<7$ hari sebanyak 90.208 bayi $(77,2 \%)$, imunisasi DPTHB-HiB (1) sebanyak 80.755 bayi (70,2\%), imunisasi DPT-HB-HiB (3) sebanyak 78.362 $(68,1 \%)$, imunisasi campak sebanyak 84.599 bayi $(73,5 \%)$, imunisasi dasar lengkap sebanyak 79.512 bayi $(69,1 \%)$.

Dari data survey awal yang dilakukan peneliti di desa Sangso didapatkan jumlah batita (1-3 tahun) adalah 81 orang. Hasil wawancara kepada 10 ibu-ibu yang memiliki anak batita usia 1-3 tahun diketahui bahwa 6 dari mereka tidak membawa anaknya untuk di imunisasi karna takut bayinya demam, dan tidak adanya izin atau dukungan dari keluarga. Dengan 
Journal of Healthcare Technology and Medicine Vol. 6 No. 2 Oktober 2020

Universitas Ubudiyah Indonesia

e-ISSN : 2615-109X

uraian tersebut berarti ibu di desa Sangso tersebut memiliki pengetahuan yang rendah karena ibu-ibu tersebut tidak mengetahui pengertian imunisasi, tujuan, manfaat, dan efek samping dari pemberian imunisasi, serta tidak adanya dorongan atau motivasi dari keluarga untuk melakukan imunisasi agar anaknya memperoleh kekebalan terhadap suatu penyakit.

Berdasarkan uraian tersebut maka peneliti tertarik untuk melakukan penelitian dengan judul "Hubungan Pengetahuan Ibu Dan Dukungan Keluarga Dengan Cakupan Pemberian Imunisasi Dasar Di Desa Sangso Kecamatan Samalanga Kabupaten Bireuen”.

Berdasarkan latar belakang diatas, maka yang menjadi rumusan masalah dalam penelitian ini yaitu "Apakah Ada Hubungan Pengetahuan Ibu Dan Dukungan Keluarga Dengan Cakupan Pemberian Imunisasi Dasar Pada Anak Usia 1-3 Tahun Di Desa Sangso Kecamatan Samalanga Kabupaten Bireuen".

Tujuan penelitian ini untuk mengetahui Hubungan Pengetahuan Ibu Dan Dukungan Keluarga Dengan Cakupan Pemberian Imunisasi Dasar Pada Anak Usia 1-3 Tahun Di Desa Sangso Kecamatan Samalanga Kabupaten Bireuen.

\section{METODE PENELITIAN}

Penelitian ini menggunakan penelitian analitik dengan pendekatan cross sectional. Lokasi penelitian di lakukan di Desa Sangso Kecamatan Samalanga Kabupaten Bireuen, dan waktu Penelitian ini dilakukan pada bulan Agustus 2020. Populasi dalam penelitian ini adalah seluruh ibu yang mempunyai anak usia batita (1-3 tahun) di Desa Sangso Kecamatan Samalanga Kabupaten Bireuen sebanyak 81 orang. Sampel dalam penelitian ini adalah keseluruhan dari populasi yang berjumlah 81 orang. Data dianalisis secara univariat dan bivariat dengan menggunakan uji chi-Square pada taraf kepercayaan 95\% ( $p<0,05)$.

\section{HASIL PENELITIAN}

Analisis Univariat digunakan untuk mengetahui distribusi frekuensi tentang cakupan pemberian imunisasi dasar, pengetahuan, dukungan keluarga.

Tabel 1. Distribusi Frekuensi Responden Berdasarkan Cakupan Pemberian Imunisasi dasar, Pengetahuan Dan Dukungan Keluarga di Desa Sangso Kecamatan Samalanga Kabupaten Bireuen Tahun 2020

\begin{tabular}{llll}
\hline \multirow{2}{*}{ Analisis Univariat } & \multicolumn{3}{c}{ Jumlah } \\
\cline { 2 - 3 } & F & $(\%)$ \\
\hline
\end{tabular}

\section{Pemberian Imunisasi Dasar}




\begin{tabular}{ccc} 
Lengkap & 16 & 19,8 \\
Tidak Lengkap & 65 & 80,2 \\
\hline Pengetahuan & 25 & \\
Baik & 10 & 30,9 \\
Cukup & 46 & 12,3 \\
Kurang & & 56,8 \\
\hline Dukungan Keluarga & 37 & 45,7 \\
Positif & 44 & 54,3 \\
Negatif & $\mathbf{8 1}$ & $\mathbf{1 0 0}$ \\
\hline Jumlah & &
\end{tabular}

Berdasarkan tabel diatas dari 81 responden, mayoritas responden tidak lengkap memberikan imunisasi dasar pada anaknya yaitu sebanyak 65 orang (80,2\%). Mayoritas responden memiliki tingkat pengetahuan kurang yaitu sebanyak 46 orang (56,8\%). Mayoritas responden mendapatkan dukungan keluarga negatif yaitu sebanyak 44 orang $(54,3 \%)$.

Analisis Bivariat digunakan untuk mengetahui hubungan antara variabel independen terhadap variabel dependen dengan menggunakan chi-square pada tingkat kemaknaan 95\% atau nilai $(\alpha=0,05)$. Bila menunjukan nilai $\mathrm{p} \leq 0,05$ artinya ada hubungan bermakna atau signifikan.

Tabel 2. Hubungan cakupan pemberian imunisasi dasar, pengetahuan, dan dukungan keluarga di Desa Sangso Kecamatan Samalanga Kabupaten Bireuen

Tahun 2020

\begin{tabular}{|c|c|c|c|c|c|c|c|}
\hline \multirow{3}{*}{ Analisis Bivariat } & \multicolumn{4}{|c|}{$\begin{array}{l}\text { Pemberian Imunisasi } \\
\text { Dasar }\end{array}$} & & & \multirow{3}{*}{ P-Value } \\
\hline & \multicolumn{2}{|c|}{ Lengkap } & \multicolumn{2}{|c|}{$\begin{array}{l}\text { Tidak } \\
\text { Lengkap }\end{array}$} & \multicolumn{2}{|c|}{$\sum$} & \\
\hline & Jlh & $\%$ & Jlh & $\%$ & Jlh & $\%$ & \\
\hline \multicolumn{8}{|l|}{ Pengetahuan } \\
\hline Baik & 16 & 19,8 & 9 & 11,1 & 25 & 30,9 & \multirow{3}{*}{0,000} \\
\hline Cukup & 0 & 0 & 10 & 12,3 & 10 & 12,3 & \\
\hline Kurang & 0 & 0 & 46 & 56,8 & 46 & 56,8 & \\
\hline \multicolumn{8}{|l|}{ Dukungan Keluarga } \\
\hline Positif & 11 & 13,6 & 26 & 32,1 & 37 & 45,7 & \multirow{2}{*}{0,074} \\
\hline Negatif & 5 & 6,29 & 39 & 48,1 & 44 & 54,3 & \\
\hline Jumlah & 16 & 19,8 & 65 & 80,2 & 39 & 100 & \\
\hline
\end{tabular}

Berdasarkan uji silang diatas dari 81 responden, mayoritas responden yang memiliki pengetahuan kurang adalah responden yang tidak lengkap memberikan imunisasi dasar kepada anaknya yaitu sebanyak 46 responden $(56,8 \%)$. 
Journal of Healthcare Technology and Medicine Vol. 6 No. 2 Oktober 2020

Universitas Ubudiyah Indonesia

e-ISSN : 2615-109X

Dari hasil uji chi square dengan tingkat kepercayaan 95\% $(\alpha=0,05)$ hasil perhitungan menunjukkan nilai $\mathrm{p}(0,000)<\alpha(0,05)$ maka Ha diterima dan Ho ditolak dan dapat disimpulkan bahwa ada hubungan yang bermakna antara pengetahuan ibu dengan cakupan pemberian imunisasi dasar di Desa Sangso Kecamatan Samalanga Kabupaten Bireuen.

Berdasarkan uji silang diatas dari 81 responden, mayoritas responden yang mendapatkan dukungan keluarga negatif adalah responden yang tidak lengkap memberikan imunisasi dasar kepada anaknya yaitu sebanyak $39 \mathrm{ibu}(48,1 \%)$,

Dari hasil uji chi square dengan tingkat kepercayaan $95 \%(\alpha=0,05)$ hasil perhitungan menunjukkan nilai nilai $\mathrm{p}(0,074)>\alpha(0,05)$ maka Ho diterima dan Ha ditolak dan dapat disimpulkan bahwa tidak ada hubungan yang bermakna antara dukungan keluarga dengan cakupan pemberian imunisasi dasar di Desa Sangso Kecamatan Samalanga Kabupaten Bireuen.

\section{PEMBAHASAN}

\section{Hubungan Pengetahuan Ibu Dengan Pemberian Imunisasi Dasar di Desa Sangso} Kecamatan Samalanga kabupaten Bireuen : Berdasarkan uji silang dari 81 responden, mayoritas responden yang memiliki pengetahuan kurang tentang pemberian imunisasi dasar yaitu sebanyak 46 responden (56,8\%), keseluruhannya adalah ibu yang tidak lengkap memberikan imunisasi dasar sebanyak 46 responden $(56,8 \%)$.

Dari hasil penelitian yang telah dilakukan tentang pengetahuan ibu dengan pemberian imunisasi dasar di Desa Sangso Kecamatan Samalanga Kabupaten Bireuen, maka ada beberapa hasil yang ditemukan antara lain, pengetahuan ibu yang ada pada kategori baik yaitu sebanyak 25 responden (30,9\%), kategori cukup 10 responden (12,3\%), dan pada kategori kurang $46(56,8 \%)$. Maka jelas dapat dilihat bahwa pengetahuan ibu mayoritas berada pada kategori kurang, sehingga perlu ditingkatkan lagi pengetahuan ibu agar lebih memahami pentingnya imunisasi dasar bagi anaknya.

Berdasarkan tabel silang (crosstab) antara pengetahuan ibu dan pemberian imunisasi dasar, ibu dengan pengetahuan baik dan melakukan pemberian imunisasi dasar secara lengkap terdiri dari 16 responden $(19,8 \%)$, selebihnya hanya 9 responden $(11,1 \%)$ yang melakukan pemberian imunisasi dasar secara tidak lengkap, dan ibu dengan pengetahuan cukup akan tetapi tidak lengkap pemberian imunisasi dasar yaitu 10 responden $(12,3 \%)$, serta ibu dengan pengetahuan kurang ada 46 responden $(56,8 \%)$ melakukan pemberian imunisasi dasar secara tidak lengkap. 
Journal of Healthcare Technology and Medicine Vol. 6 No. 2 Oktober 2020

Universitas Ubudiyah Indonesia

e-ISSN : 2615-109X

Hasil uji statistik chi-square dengan tingkat kepercayaan 95\% $(\alpha=0,05)$ antara pengetahuan ibu dengan pemberian imunisasi dasar diperoleh hasil nilai $\mathrm{p}$ value $(0,000<$ dari $\alpha(0,05)$, maka $\mathrm{H}_{0}$ ditolak dan $\mathrm{H}_{\mathrm{a}}$ diterima dan dapat disimpulkan bahwa ada hubungan yang bermakna antara pengetahuan ibu dengan cakupan pemberian imunisasi dasar.

Hal ini menunjukkan bahwa pengetahuan ibu masih kurang dalam hal pemberian imunisasi dasar. Faktor-faktor yang mempengaruhi pengetahuan adalah pendidikan, informasi/media massa, sosial, budaya dan ekonomi, lingkungan, pengalaman, dan usia (Budiman, 2013).

Penyebab bayi tidak mendapatkan imunisasi lengkap adalah karena alasan informasi dan motivasi. Alasan informasi berupa kurangnya pengetahuan ibu tentang kebutuhan, kelengkapan dan jadwal imunisasi, ketakutan akan imunisasi dan adanya persepsi salah yang beredar di masyarakat tentang imunisasi. Alasan motivasi berupa penundaan imunisasi, kurangnya kepercayaan tentang manfaat imunisasi dan adanya rumor yang buruk tentang imunisasi. Namun yang paling berpengaruh adalah karena anak sakit, ketidaktahuan ibu akan pentingnya imunisasi, ketidaktahuan waktu yang tepat untuk mendapatkan imunisasi berikutnya dan ketakutan akan efek samping imunisasi. Hal ini menunjukan bahwa pengetahuan sangat berperan penting dalam pemberian imunisasi pada bayi (Dewi, 2013).

Pengetahuan adalah hasil penginderaan manusia, atau hasil tahu seseorang terhadap suatu objek dari indra yang dimilikinya (Notoatmodjo, 2012). Penginderaan terjadi melalui panca indera manusia, yakni indera penglihatan, pendengaran, penciuman, perasa, dan peraba. Sebagian besar pengetahuan manusia diperoleh melalui mata dan telinga. Oleh karena itu, semakin banyak hal positif yang didengar dan dilihat oleh seseorang maka semakin besar pula tindakan positif yang dilakukan orang tersebut (Notoatmodjo, 2009).

Penelitian terdahulu yang dilakukan oleh Razana Hijani (2013) mengenai "Hubungan Pengetahuan Ibu Tentang Imunisasi Terhadap Kelengkapan Imunisasi Dasar Pada Balita Di Wilayah Kerja Puskesmas Dumai Kota Kelurahan Dumai Kota” menunjukkan hasil analisa hubungan pengetahuan ibu tentang imunisasi terhadap kelengkapan imunisasi dasar pada balita dengan menggunakan uji chi square menunjukkan $\mathrm{p}$ value sebesar 0,000 dimana $\mathrm{p}$ value $<0.05$. Hal ini berarti Ho ditolak dan dapat disimpulkan ada hubungan pengetahuan ibu tentang imunisasi terhadap kelengkapan imunisasi dasar pada balita di wilayah kerja Puskesmas Dumai Kota Kelurahan Dumai Kota.

Menurut asumsi peneliti, mayoritas ibu berpengetahuan kurang sebanyak 46 responden $(56,8 \%)$ dikarenakan para ibu kurang mengetahui tentang imunisasi dasar termasuk efek 
Journal of Healthcare Technology and Medicine Vol. 6 No. 2 Oktober 2020

Universitas Ubudiyah Indonesia

e-ISSN : 2615-109X

sampingnya. Faktor pengetahuan memegang peranan penting dalam pemberian kelengkapan imunisasi dasar, karena pengetahuan mendorong kemauan dan kemampuan masyarakat, sehingga akan diperoleh suatu manfaat terhadap keberhasilan imunisasi secara lengkap. Semakin tinggi tingkat pengetahuan seseorang maka makin mudah seseorang menerima informasi tetapi sebaliknya dengan pengetahuan yang rendah akan menghambat seseorang untuk mendapatkan atau menerima suatu informasi.

Hubungan Dukungan Keluarga Dengan Pemberian Imunisasi Dasar di Desa Sangso Kecamatan Samalanga kabupaten Bireuen : Berdasarkan uji silang dari 81 responden, mayoritas responden memiliki dukungan keluarga yang negatif yaitu sebanyak 44 responden $(54,3 \%)$, yang terdiri dari ibu yang lengkap memberikan imunisasi dasar sebanyak 5 responden $(6,29 \%)$ dan ibu yang tidak lengkap memberikan imunisasi dasar sebanyak 39 responden $(48,1 \%)$.

Dari hasil penelitian yang telah dilakukan, tentang dukungan keluarga dengan pemberian imunisasi dasar di Desa Sangso Kecamatan Samalanga Kabupaten Bireuen, maka ada beberapa hasil yang ditemukan antara lain, dukungan keluarga yang positif yaitu sebanyak 37 responden $(45,7 \%)$ dan yang negatif sebanyak 44 responden $(54,3 \%)$.

Berdasarkan tabel silang antara dukungan keluarga dengan pemberian imunisasi dasar, didapatkan hasil bahwa ibu yang memiliki dukungan keluarga positif namun tidak lengkap memberikan imunisasi dasar sebanyak 26 responden $(32,1 \%)$, selebihnya hanya 11 responden $(13,6 \%)$ yang memberikan imunisasi dasar lengkap, dan 39 responden $(48,1 \%)$ yang memiliki dukungan keluarga negatif dan tidak lengkap memberikan imunisasi dasar untuk anaknya, selebihnya hanya 5 responden $(6,29 \%)$ yang dukungan keluarga nya negatif dan lengkap melakukan pemberian imunisasi dasar.

Hasil uji statistik chi-square dengan tingkat kepercayaan 95\% $(\alpha=0,05)$ antara sikap ibu dengan pemberian imunisasi dasar diperoleh hasil nilai $\mathrm{p}$ value $(0,074)>$ dari $\alpha(0,05)$, maka $\mathrm{H}_{0}$ diterima dan $\mathrm{H}_{\mathrm{a}}$ ditolak dan dapat disimpulkan bahwa tidak ada hubungan yang bermakna antara dukungan keluarga dengan pemberian imunisasi dasar.

Hal ini tidak sejalan dengan pendapat (Supriyanto, 2011) yaitu faktor yang mempengaruhi kelengkapan imunisasi dasar adalah pendidikan, pendapatan, pengetahuan, sikap, motif, pengalaman, pekerjaan, dukungan keluarga, fasilitas posyandu dan lingkungan.

Teori lingkungan kebudayaan dimana orang belajar banyak dari lingkungan kebudayaan. Pengaruh keluarga terhadap pembentukan sikap sangat besar karena keluarga merupakan orang yang paling dekat dengan anggota keluarga yang lain. Jika sikap keluarga 
Journal of Healthcare Technology and Medicine Vol. 6 No. 2 Oktober 2020

Universitas Ubudiyah Indonesia

e-ISSN : 2615-109X

terhadap imunisasi kurang begitu respon dan bersikap tidak menghiraukan pelaksanaan kegiatan imunisasi maka imunisasi tidak akan dilakukan oleh ibu bayi karena tidak ada dukungan keluarga (Supriyanto, 2011).

Dukungan keluarga menurut Friedman (2010) adalah sikap, tindakan penerimaan keluarga terhadap anggota keluarganya, berupa dukungan informasional, dukungan penilaian, dukungan instrumental dan dukungan emosional. Jadi dukungan keluarga adalah suatu bentuk hubungan interpersonal yang meliputi sikap, tindakan dan penerimaan terhadap anggota keluarga, sehingga anggota keluarga merasa ada yang memperhatikan.

Penelitian terdahulu yang dilakukan oleh Hermiati (2014) mengenai "Hubungan Dukungan Suami Dan Pengetahuan Ibu Bayi Pemberian Imunisasi Dasar Di Desa Jegged Ayu Kecamatan Jagong Jeged Kabupaten Aceh Tengah" menunjukkan hasil ada hubungan antara pengetahuan terhadap pemberian imunisasi dasar pada bayi, p value $<$ nilai $\alpha(0,000<0,05)$. Ada hubungan antara dukungan suami terhadap pemberian imunisasi dasar pada bayi $\mathrm{p}$ value $<$ nilai $\alpha(0,000<0,05)$.

Peneliti berasumsi bahwa diperlukannya beberapa himbauan ataupun informasi tentang imunisasi dasar lengkap yang dapat mengarahkan individu yang khususnya seorang ibu ataupun anggota keluarga lainnya agar munculnya dukungan keluarga terhadap ibu untuk melaksanakan imunisasi dasar lengkap dan membentuk opini keluarga maupun ibu yang baik terhadap suatu hal, khususnya dalam penelitian ini yaitu tentang dukungan keluarga dengan cakupan pemberian imunisasi dasar dan juga dapat didukung dengan adanya promosi kesehatan yang dilakukan oleh petugas kesehatan yang memiliki pengetahuan yang cukup tentang imunisasi dasar lengkap. Sehingga, besar kemungkinan untuk terciptanya opini, percaya, nyaman, aman, dan perilaku melaksanakan imunisasi dasar, serta diperlukannya komunikasi yang persuasif melalui promosi kesehatan maupun pendidikan kesehatan sehingga responden lebih memahami mengenai informasi yang mereka dapatkan untuk meningkatkan kesadaran mereka mengenai pentingnya imunisasi dasar lengkap pada bayi/balita.

\section{KESIMPULAN}

Kesimpulan penelitian ini ada hubungan antara pengetahuan dengan cakupan pemberian imunisasi dasar dan tidak ada hubungan antara dukungan keluarga dengan cakupan pemberian imunisasi dasar di Desa Sangso Kecamatan Samalanga Kabupaten Bireuen tahun 2020. 
Journal of Healthcare Technology and Medicine Vol. 6 No. 2 Oktober 2020

Universitas Ubudiyah Indonesia

e-ISSN : 2615-109X

\section{SARAN}

Disarankan kepada responden untuk lebih aktif mencari informasi dan mengikuti berbagai penyuluhan khususnya tentang pemberian imunisasi dasar dan manfaatnya, hal ini dapat diperoleh dengan mengunjungi tempat pelayanan kesehatan dan diharapkan kepada tenaga kesehatan untuk lebih aktif lagi dalam mensosialisasikan pentingnya imunisasi dasar bagi anak dan mampu memotivasi ibu untuk memberikan imunisasi pada anaknya.

\section{DAFTAR PUSTAKA}

Akmal, M. 2016. Ensiklopedi Kesehatan. Ar - Ruzz Media. Jogjakarta

Depkes RI. 2016. http://www.depkes.go.id/resources/download/pusdatin/profil-kesehatanindonesia/Profil-Kesehatan-Indonesia-2016.pdf

Dewi. 2010. Asuhan Neonatus Bayi dan Anak Balita. Salemba Medika. Jakarta

Dewi, A.P. 2013. Hubungan Tingkat Pengetahuan Ibu dengan Pemberian Imunisasi Dasar Lengkap pada Bayi di Kelurahan Parupuk Tabing Wilayah Kerja Puskesmas Lubuk Buaya Kota Padang Tahun 2013. http://jurnal.fk.unand.ac.id/index.php/jka/article/view/43

Hadianti, D.N. 2014. Buku Ajar Imunisasi. Pusat Pendidikan dan Pelatihan Tenaga Kesehatan. Jakarta.

Harmasdiyani, R. 2015. Pengaruh Karakteristik Ibu Terhadap Ketidakpatuhan Pemberian Imunisasi Dasar Lengkap Pada Anak Bawah Dua Tahun. https://ejournal.unair.ac.id/JBE/article/download/1670/1287

Hermiati. 2014. Hubungan Dukungan Suami Dan Pengetahuan Ibu Bayi Dengan Pemberian Imunisasi Dasar Di Desa Jeged Ayu Kecamtan Jagong Jeged Kabupaten Aceh Tengah. http://simtakp.uui.ac.id/docjurnal/HERMIATI-jurnal_hermiati.pdf

Ilham. 2017. Hubungan Dukungan Keluarga Dengan Kepatuhan Ibu Melaksanakan Imunisasi Dasar Lengkap Pada Bayi Di Wilayah Kerja Puskesmas Pemangkat Kabupaten Sambas. http://jurnal.untan.ac.id/index.php/jmkeperawatanFK/article/viewFile/22357/17797

Iman, M. 2016. Panduan Penyusunan Karya Tulis Ilmiah Bidang Kesehatan. Cita Pusaka: Medan.

. 2014. Pemanfaatan SPSS Dalam Penelitian Bidang Kesehatan \& Umum. Cita Pusaka: Medan.

Lisnawati, L. 2011. Generasi Sehat Melalui Imunisasi. TIM. Jakarta

Maryanti, D. 2011. Buku Ajar Neonatus, Bayi, dan Balita. TIM. Jakarta

Mushlihah, I. 2017. Hubungan Pengetahuan Ibu Dan Dukungan Keluarga Terhadap Imunisasi Dengan Status Imunisasi Di Wilayah Kerja Puskesmas Sempor I. http://elib.stikesmuhgombong.ac.id/558/1/INTAN\%20MUSHLIHAH\%20NIM.\%20A 11300900.pdf

Nurwulan, D. 2017. Hubungan Dukungan Keluarga Dengan Tingkat Kecemasan Pada Pasien Pre Anastesi Dengan Tindakan Spinal Anastesi Di RSUD Sleman. https://eprints.poltekkesjogja.ac.id/433/1/SKRIPSI.pdf

Pertiwi, P. 2012. Gambaran Faktor-faktor Yang Mempengaruhi Pemberian ASI Ekslusif di Kelurahan Kunciran Indah Tangerang. 
Journal of Healthcare Technology and Medicine Vol. 6 No. 2 Oktober 2020

Universitas Ubudiyah Indonesia

e-ISSN : 2615-109X

https://www.google.com/search?client=firefoxb\&q=related:lib.ui.ac.id/file\%3Ffile\%3 Ddigital/20312381-S\%252043138

Gambaran\%2520faktorfull\%2520text.pdf+partiwi++2012+tentang+sikap+ibu\&tbo=1 $\& s a=X \& v e d=0$ ahUKEwi0qsjcpLncAhWKPo8KHdp3DN4QHwgyMAA\&biw=1350\& bih $=647$

Ritonga, M.R.S. 2014. Hubungan Antara Dukungan Keluarga Terhadap Kepatuhan Ibu Melaksanakan Imunisasi Dasar Pada Anak Di Desa TigaboloN Kecamatan Sidamanik Kabupaten Simalungun Tahun 2014. http://14357-ID-hubungan-antara-dukungankeluarga-terhadap-kepatuhan-ibu-melaksanakan-imunisasi.pdf

Rukiyah, A.Y. 2010. Asuhan Neonatus Bayi dan Anak Balita. TIM. Jakarta.

Sari, D.N.I. 2015. Hubungan Pengetahuan Ibu Tentang Imunisasi Dasar Dengan Kelengkapan Imunisasi Dasar Bayi Di Wilayah Kerja Pusklesmas Bendo Kabupaten Magetan. http://journals.ums.ac.id/index.php/biomedika/article/download/2910/1832 